\title{
Expression of Multidrug and Toxic Compound Extrusion (MATE) Genes in Response to the Presence of Arsenic in Irrigation Water and Soil in Rice (Oryza sativa L.)
}

\author{
S. Debnath ${ }^{* \#}$, S. Bhattacharyya, S. Sarkar and M. Chatterjee \\ Dept. of Genetics \& Plant Breeding and Crop Research Unit, Bidhan Chandra Krishi Viswavidyalaya, Nadia, \\ West Bengal (741 252), India \\ "Presently Dept. of CIHAB, Institute of Agriculture, Visva-Bharati, Sriniketan, West Bengal (731 236), India
}

\section{Article History}

Manuscript No. AR1488

Received in $6^{\text {th }}$ November, 2015

Received in revised form $30^{\text {th }}$ January, 2016

Accepted in final form $5^{\text {th }}$ February, 2016

\section{Correspondence to}

*E-mail: sandip.debnath@visva-bharati.ac.in

\section{Keywords}

Rice, arsenic, MATE, RNA, gene expression

\begin{abstract}
The problem of arsenic in diet through rice is going to be a great challenge in the coming days especially in India and Bangladesh. Several management technologies have already been recommended to encounter the problem of arsenic in crops and thereby in daily diet. In this regard, plant's inbuilt defense mechanism may be utilized here. Likewise, to mitigate the issue, toxic compound extrusion genes are needed to be studied in detail. These genes play an important role in the detoxification of secondary metabolites, including alkaloids. So, we investigated the response of different Multidrug and toxic compound extrusion (MATE) genes in straw and grain of rice challenged to the presence of arsenic in irrigation water and soil. Relative expression of Multidrug and toxic compound extrusion transporter genes located on chromosome 3, 5, 10 and 12 were measured in two contrasting rice genotypes. These genes were assumed to be arsenic responsive as expression of all these genes in Satika (low accumulator) was higher than that of TN 1 (high accumulator) in control condition and expression increased significantly in both the genotypes when arsenic was present in soil. Particularly, LOC_Os05g48040 might have some role in sequestration of arsenic in stem and thus reducing arsenic in grain revealed through validation in rice genotypes contrasting for arsenic accumulation. This gene may play a pivotal role to understand the route of arsenic detoxification in rice and thereby develop a breeding strategy.
\end{abstract}

\section{Introduction}

Rice accumulates higher amount of arsenic than that of other cereals (Williams et al., 2007). Thus rice is one of the potential crops for human exposure to arsenic (Sohn, 2014). Moreover, arsenic contaminated groundwater is used as a major source of irrigation for growing crop in vast area of West Bengal and Bangladesh (Huq et al., 2006) where majority of diet is rice-based. Thus it is entering into the crop plants vis-à-vis mobilized into all parts of rice. Exposure of arsenic in diets is linked with cancers of the bladder, lungs, skin and prostate, as well as heart disease (Sohn, 2014). Indeed arsenic cannot be removed from this vast contaminated area. So, identifying low arsenic up-taking rice genotypes and the genes responsible for detoxification of arsenic in rice might be a possible option. Thus to develop low arsenic accumulating rice, it is mandatory to identify the route and their associated genes responsible for arsenic translocation from soil to grain. In this context, MATE genes, comprising the most recently designated family of multidrug transporters were taken into consideration in the present study and finding their utility to detoxify the metalloid in plant system. Furthermore, the candidate gene may be exploited for designing gene based molecular marker. These proteins are widely distributed in all kingdoms of living organisms, although their biological role little understood. Plant MATE-type transporters play pivotal roles in the detoxification of secondary metabolites, including alkaloids. It comprises a varied range of functions including the transport of lipophilic cations and other related compounds (Debeaujon et al., 2001). In a whole genome transcriptional experiment, seven MATE transporters were found to be upregulated (LOC_Os03g37490, LOC_Os05g48040, LOC_ Os08g37430, LOC_Os08g37432, LOC_Os10g20450, LOC_ Os10g20470, and LOC_Os12g03260) and two down-regulated 
(LOC_Os04g48290 and LOC_Os09g29284) in root tissue of rice seedlings when challenge with sodium arsenate in hydroponic solution (Norton et al., 2008). In this study, the alterations in gene expression of these nine genes were examined. But out of these nine genes, four loci located on chromosome 3, 5, 10 and 12 (one from each) viz., LOC Os10g20470, LOC_Os03g37490, LOC_Os05g48040 and LOC_Os12g03260 were found to responsive when treated with arsenate in the present study. So, the relative expressions of these four genes were studied primarily in two genotypes contrasting in their ability to accumulate arsenic. Further, the relative expression of the most responsive MATE gene was validated in eight differential rice genotypes.

\section{Materials and Methods}

\subsection{Selection of plant material}

Eight rice genotypes viz., IR 64, Choli 60, Gobindabhog, Rasi, TN 1, Satika, Satabdi and Palman were cultivated for two successive kharif and boro seasons in 2010-11 and 2011-12. The experiment was laid out in a randomized complete block design with three replications and $3 \times 3 \mathrm{~m}^{2}$ plots. Standard dose (70:30:30) of N, P, K was applied of which nitrogen was applied in three equal splits. The arsenic loading of the ground water which was used as irrigation source in farmer's field was $0.53 \mathrm{mg} \mathrm{l}^{-1}$ and Olsen extractable arsenic in soil was $4.9 \mathrm{mg}$ $\mathrm{kg}^{-1}$. Control site was selected at regional research substation of the university situated at Sekhampur, Birbhum, West Bengal.

Satika and TN1, two genotypes were selected for pot experiment based on their same duration for maturity. But these lines were contrasting for their arsenic accumulation in grain (Chatterjee et al., 2013). These two genotypes were grown in plastic pots with three replications. Each pot was filled with $5 \mathrm{~kg}$ of soil. Treated pots were amended with the Arsenic (V) oxide hydrate, (Sigma 363456-25G) at the rate of $5 \mathrm{mg}$ or 10 $\mathrm{mg}$ per $\mathrm{kg}$ of soil on the other hand no treatment with arsenic was followed in control pots. Flowering was delayed due to addition of arsenic in the soil, particularly when $5 \mathrm{mg} \mathrm{kg}^{-1}$ or above dose was amended. Arsenic accumulation pattern of the pot-grown seeds were given in Table 1.

\subsection{Arsenic estimation}

Husk and brown rice of mature grain were separated using palm-husker. Total as was estimated from oven dried plant parts. Olsen extractable As content of the studied soils was determined by extracting soil with $0.5(\mathrm{M}) \mathrm{NaHCO}_{3}(\mathrm{pH}$ 8.5) in 1:10 ratio for one hour followed by estimation using the atomic absorption spectrophotometer (Perkin Elmer AANALYST 700) coupled with Flow Injection Analysis System (FIAS 400) as described by Mukhopadhyay et al., 2004. $\mathrm{pH}$ and Olsen extractable arsenic of Nonaghata soil was 6.83 and $16.65 \mathrm{mg} \mathrm{kg}^{-1}$, respectively where as it was 5.8 and $2.65 \mathrm{mg} \mathrm{kg}^{-1}$ at Sekhampur farm.

\subsection{Relative gene expression analysis}

Total RNA of eight photo-insensitive genotypes were extracted using RNeasy plant mini kit (Qiagen) treated with RNase free DNase, stem and grain harvested at eighteen days after fertilization according to the manufacturer's instructions. First-strand cDNA was synthesized from 5 microgram of total RNA using oligo-dT (18) primer and Super Script FirstStrand Synthesis system for RT-PCR (Applied Biosystem). Transcript levels of target genes were measured by quantitative RT-PCR (Bhattacharyya et al., 2003). Relative quantification of candidate mRNA was performed in $20 \mu \mathrm{l}$ reaction volume containing $2 \mu \mathrm{l}$ cDNA, $200 \mathrm{nM}$ each gene-specific primers, and SYBR Premix (Applied Biosystem) using Step One (Applied Biosystem) machine. Normalization of target gene expression with housekeeping gene ( $\beta$-tubulin) was useful in order to compensate sample to sample variations and to ensure the experimental reliability. For quantification of relative expression of various genes in this study, the RQ value for the samples TN1 Control/TN1 was taken as one and the primers are listed in Table 4.

\section{Results and Discussion}

In the present study, four MATE genes located on chromosome $3,5,10$ and 12 were taken into consideration for their response in two pot-grown genotypes, TN1 and Satika where soil was amended with $5 \mathrm{mg} \mathrm{kg}^{-1}$ and $10 \mathrm{mg} \mathrm{kg}^{-1}$ of arsenate. These genes were LOC_Os10g20470, LOC_Os03g37490, LOC_Os05g48040 and LOC_Os12g03260. The rest three genes showed no considerable response when challenged with arsenate. Expression of all these genes in Satika was higher than that of TN1 in control condition and expression increased significantly in both the genotypes when arsenic was present in soil (dose of $5 \mathrm{mg} \mathrm{kg}^{-1}$ ). Interestingly, expression of LOC_Os10g20470 and LOC_Os12g03260 increased steadily in TN1, particularly, when higher dose of $(10 \mathrm{mg}$ $\mathrm{kg}^{-1}$ ) arsenate was present in soil whereas Satika registered

Table 1: Mean arsenic content of different rice tissues with different doses of arsenate

\begin{tabular}{lcc}
\hline Treatment & \multicolumn{2}{c}{$\begin{array}{l}\text { Total Arsenic content } \\
\left(\mathrm{mg} \mathrm{kg}^{-1}\right) \\
\text { arsenate }\end{array}$} \\
\cline { 2 - 3 } & in presence of \\
& 0.173 & grain \\
\hline Satika Control & 0.165 & 0.064 \\
TN 1 Control & 2.453 & 0.146 \\
Satika (5 mg kg-1 of soil) & 2.113 & 0.288 \\
TN 1 (5 mg kg-1 of soil) & 2.418 & 0.365 \\
Satika (10 mg kg-1 of soil) & 3.216 & 0.943 \\
TN 1 (10 mg kg-1 of soil) & & \\
\hline
\end{tabular}


repression. MATE proteins are found in bacteria, archaea and eukaryotes. Characterized members of the MATE family function as drug/sodium antiporters. These proteins mediate resistance to a wide range of cationic dyes, fluroquinolones, aminoglycosides and other structurally diverse antibodies and drugs. Recently, it has been also reported that, some MATE proteins are involved in the transport of citrate, which is required for iron $(\mathrm{Fe})$ translocation or aluminum detoxification (Yokosho et al., 2009). Aluminum-inducible MATE expression was associated with induction of aluminum tolerance via enhanced root citrate exudation (Magalhaes et al., 2007). The secondary transporter, MATE, was also induced in As treated seedlings after $24 \mathrm{hrs}$ of exposure to As V in Crambe abyssinica (Paulose et al., 2010). The results of the present study also corroborated with this finding as MATE genes were found to responsive in As V treatment. It can be assumed that, expression of MATE in stem of rice might have some role in sequestration of arsenic in stem or husk and result reduced accumulation in grain or brown rice.

Other than LOC_Os05g48040, rest three genes might not have any relation with As accumulation in grain. But LOC Os10g20470 and LOC_Os12g03260 might be involved in arsenic resistance to rice plants to some extent. Spectacularly, expression of LOC_Os05g48040 in TN1-grain was lower than Satika but it registered 189 fold increase than that of control where as it was only 10 fold increase in Satika (Table 2). So, this MATE gene may be deduced to be arsenate responsive. LOC_Os05g48040 is located on chromosome 5 and ORF of this gene is $1,227 \mathrm{bp}$ long. It encodes putative MATE efflux protein localized in the chloroplast and plasma membrane. This gene plays pivotal roles in biological processes like cadmium ion transport, response to wounding, sequestering of metal ion and having molecular functions of antiporter activity and transmembrane drug transporter activity (UniProtKB-Q6I630). Upon validation, significant negative correlation was found between expression of LOC_ Os05g48040 gene in stem and arsenic content in whole grain $(\mathrm{r}=-0.533)$ and similar result was found between expression of the gene in spikelet at grain filling stage and arsenic content of brown rice at maturity $(\mathrm{r}=-0.621)$. So there was a role of LOC_Os05g48040 gene for reducing brown rice arsenic accumulation may be presumed from the present study. Highest expression of LOC_Os5g48040 was found in Satika spikelet followed by Gobindabhog (Table 3). Both the genotypes were low arsenic accumulating in their grain. Thus, higher expression of MATE in spikelet may able to partitioning the toxic metalloids in such a way as it can reduce the upload of As in the grain. This gene may be regarded as a useful arsenic transporter gene for designing

\begin{tabular}{|c|c|c|c|c|}
\hline Treatments & Os10g20470 & Os03g37490 & Os05g48040 & Os $12 \mathrm{~g} 03260$ \\
\hline Satika Control & 3.6 & 5 & 27.51 & 2.49 \\
\hline TN1 Control & 1 & 1 & 1 & 1 \\
\hline Satika AsV $5 \mathrm{mg} \mathrm{kg}^{-1}$ of soil & 115.68 & 80.93 & 275.11 & 118.46 \\
\hline TN1 As V5 $\mathrm{mg} \mathrm{kg}^{-1}$ of soil & 48.04 & 38.82 & 189.39 & 18.2 \\
\hline Satika AsV10 $\mathrm{mg} \mathrm{kg}^{-1}$ of soil & 10.64 & 10.77 & 143.9 & 8.74 \\
\hline TN1 As V10 $\mathrm{mg} \mathrm{kg}^{-1}$ of soil & 38.31 & 83.11 & 211.04 & 35.63 \\
\hline
\end{tabular}

Table 3: Relative expression of LOC_Os05g48040 gene in stem and grain during dough stage when grown on arsenic contaminated soil and their correlation with arsenic accumulation in grain, brown rice, husk and straw

\begin{tabular}{|c|c|c|c|c|c|c|}
\hline \multirow[t]{2}{*}{ Genotype } & \multicolumn{2}{|c|}{ RQ of LOC_Os05g48040 } & \multicolumn{4}{|c|}{ Arsenic accumulation $\left(\mathrm{mg} \mathrm{kg}^{-1}\right)$} \\
\hline & Stem & Grain & Grain & Brown rice & Husk & Straw \\
\hline 60 Choli & 1.24 & 1.75 & 0.281 & 0.24 & 0.102 & 2.775 \\
\hline Gobindabhog & 3.56 & 8.58 & 0.056 & 0.048 & 0.112 & 0.384 \\
\hline IR-64 & 0.41 & 2.19 & 0.462 & 0.146 & 0.354 & 2.344 \\
\hline Palman & 0.32 & 2.21 & 0.32 & 0.136 & 0.236 & 4.491 \\
\hline Rasi & 0.86 & 2.10 & 0.426 & 0.286 & 0.221 & 1.02 \\
\hline Satabdi & 1.05 & 1.99 & 0.378 & 0.359 & 0.052 & 2.07 \\
\hline Satika & 4.86 & 10.05 & 0.216 & 0.117 & 0.134 & 2.302 \\
\hline TN1 & 1 & 1 & 0.892 & 0.597 & 1.12 & 1.74 \\
\hline \multicolumn{3}{|c|}{ Correlation of RQ of LOC Os $05 \mathrm{~g} 48040$ in stem and } & -0.533 & -0.420 & -0.278 & -0.375 \\
\hline \multicolumn{3}{|c|}{ Correlation of RQ of LOC_Os05g48040 in grain and } & -0.657 & -0.621 & -0.380 & -0.320 \\
\hline
\end{tabular}


Table 4: List of primers for RT-PCR study

\begin{tabular}{lll}
\hline Gene & Forward primer $\left(5^{\prime}-3^{\prime}\right)$ & Reverse primer $\left(5^{\prime}-3^{\prime}\right)$ \\
\hline Os10g20470 & GCAGCGCACAACATCTCGGA & GGATTGTGCTTTCTTGTCACTGCCC \\
Os03g37490 & TGGGGGTGAATGGACTGGCTT & GACGGATTTACAGGTCCGGCAAT \\
Os05g48040 & GCTGTTTGCAGCACAGCGCA & CCGCAACCCCGAGCAATACCTG \\
Os12g03260 & GCTAAGCCAAGCTGTGCTAGGAG & CGCGCAGATGGAAGGACCCG \\
\hline
\end{tabular}

a gene based marker (Varshney, 2009) like InDel or SNP markers (Hayashi et al., 2006) which would be important tool for developing low arsenic accumulating genotype through marker assisted breeding.

\section{Conclusion}

Restriction of arsenic transport to the grain is assumed to be a great factor in reducing grain arsenic accumulation. Therefore, LOC_Os5g48040 might be a key player in this issue. Being a high accumulator, rice is always a principal source of arsenic in food in the huge area of India and Bangladesh. So, Breeding of low arsenic accumulator rice variety is the only alternative here. So, marker assisted breeding by using gene based markers of LOC Os5g48040 may open up a new direction towards mitigation of the problem.

\section{Acknowledgement}

We sincerely acknowledge ICAR-Niche area of excellence programme, 'Arsenic management options including organic agricultural systems in West Bengal' and ICAR-NAIP project, 'Arsenic in food chain: cause effect and mitigation' for generous funding and Sandip Debnath acknowledges the INSPIRE fellowship programme of DST, GOI for providing financial assistance during his doctoral study.

\section{References}

Bhattacharyya, S., Pattanaik, S.K., Maiti, I.B., 2003. Intron mediated enhancement of gene expression in transgenic plants using chimeric constructs composed of peanut chlorotic streak virus (PCISV) promoter-leader and the antisense orientation of PCISV ORFVII (p7R). Planta 218, 115-124.

Chatterjee, M., Sarkar, S., Debnath, S., Mukherjee, A., Chakraborty, A., Bhattacharyya, S., 2013. Genotypic difference in temporal variation of arsenic accumulation and expression of silicon efflux transporter $\left(\mathrm{LSi}_{2}\right)$ gene in field grown rice. Indian Journal of Genetics and Plant Breeding 73, 94-97.

Debeaujon, I., Peeters, A.J.M., Le'on-Kloosterziel, K.M., Koornneef, M., 2001. The transparent testa12 gene of Arabidopsis encodes a multidrug secondary transporterlike protein required for flavonoid sequestration in vacuoles of the seed coat endothelium. The Plant Cell 13, 853-871.
Hayashi, K., Yoshida, H., Ashikawa, I., 2006. Development of PCR-based allele-specific and InDel marker sets for nine rice blast resistance genes. Theoretical and Applied Genetics 113(2), 251-260.

Huq, S.I., Joardar, J.C., Parvin, S., Correll, R., Naidu, R., 2006. Arsenic contamination in food-chain: transfer of arsenic into food materials through groundwater irrigation. Journal of health, population, and nutrition 24(3), 305 .

Magalhaes, J.V., Liu, J., Guimarães, C.T., Lana, U.G., Alves, V.M., Wang, Y.H., Schaffert, R.E., Hoekenga, O.A., Piñeros, M.A., Shaff, J.E., Klein, P.E., Carneiro, N.P., Coelho, C.M., Trick, H.N., Kochian, L.V., 2007. A gene in the multidrug and toxic compound extrusion (MATE) family confers aluminum tolerance in sorghum. Nature Genetics 39(9), 1156-1161.

Mukhopadhyay, D., Sanyal, S.K., 2004. Complexation and release isotherm of arsenic in arsenichumic/fulvic equilibrium study. Australian Journal of Soils Research 42, 815-824.

Norton, G.J., Lou-Hing, D.E., Meharg, A.A., Price, A.H., 2008. Rice-arsenate interactions in hydroponics: whole genome transcriptional analysis. Journal of Experimental Botany 8, 2267-2276.

Paulose, B., Kandasamy, S., Dhankher, O.P., 2010. Research article Expression profiling of Crambe abyssinica under arsenate stress identifies genes and gene networks involved in arsenic metabolism and detoxification. BMC Plant Biology 10:108. doi: 10.1186/1471-2229-10-108.

Sohn, E., 2014. Contamination: The toxic side of rice. Nature 514(7524), S62-S63.

Varshney, R.K., 2009. Gene-based marker systems in plants: high throughput approaches for marker discovery and genotyping. In Molecular techniques in crop improvement (119-142). Springer Netherlands.

Williams, P.N., Villada, A., Deacon, C., Raab, A., Figuerola, J., Green, A.J., Feldmann, J., Meharg, A.A., 2007. Greatly enhanced arsenic shoot assimilation in rice leads to elevated grain concentrations compared to wheat and barley. Environmental Science and Technology 41, 6854-6859. Doi,10.1021/es070627i.

Yokosho, K., Yamaji, N., Ueno, D., Mitani, N., Ma, J.F., 2009. OsFRDL1 Is a Citrate Transporter Required for Efficient Translocation of Iron in Rice. Plant Physiology 149(1), 297-305. 